\title{
DO WHAT THOU WILT SHALL BE THE WHOLE OF THE LAW: RAUL SEIXAS'S CONTRIBUTIONS TO THE STUDY OF LAW
}

\author{
Horácio Wanderlei Rodrigues ${ }^{1}$ \\ Leilane Serratine Grubba ${ }^{2}$ \\ Amanda Muniz Oliveira ${ }^{3}$
}

\begin{abstract}
This article aims to demonstrate how rock, a media product derived from mass culture, can be used as a vehicle of social struggle, based on the example of Raul Seixas. Having achieved public success in the Brazilian dictatorial period, the artist tried to use his social status and his audience to disseminate ideals related to individual freedom. Knowing the Law of Thelema, Raul recreated this esoteric postulate and applied it in the social and political field, in order to diffuse its premises as a form of struggle and resistance against the dictatorship. The article, in this sense, will propose the use of rock as a way of reflecting about the law. For this, methodologically, we will investigate how and why rock should be considered a promising source of legal studies; in the sequence, the Brazilian situation of the 70's will be contextualized, the most successful time of Raul Seixas, and we will investigate the way the artist used his prominent place to denounce and challenge the status quo.
\end{abstract}

Keywords: Freedom; Law \& Music; Raul Seixas; Rock; Legal knowledge.

\footnotetext{
${ }^{1}$ Doutor e Mestre em Direito pela UFSC. Estágios de Pós-Doutorado em Filosofia/UNISINOS e em Educação/UFRGS. Professor Permanente do PPG Direito/IMED/RS. Professor Colaborador do PPGD/UFSC. Sócio fundador do CONPEDI e da ABEDi. Membro do Instituto Iberomericano de Derecho Procesal. Pesquisador do CNPq e da Fundação Meridional. E-mail: horaciowr@gmail.com

${ }^{2}$ Doctor of Law (UFSC), Master in Law (UFSC) and is studying at Fronteira Sul Federal University's Interdisciplinary Master's in Human Sciences (UFFS). She had completed her Post-doctoral internship at Federal University of Santa Catarina. Permanent Professor of Law at Faculdade Meridional (IMED). Researcher at Fundação Meridional. Coordinator of the Research Project FUNDDIH - Foundations and Dimensions of Human Rights (IMED / CNPq). Coordinator of CineLaw Research and Extension Project - Cinema, Human Rights and Society: ways for Empowerment (CNPq / IMED), supported by the InterAmerican Institute of Human Rights (IIHR) and the Youth for Human Rights (YHRB) Program. E-mail: Isgrubba@hotmail.com ${ }^{3}$ Doctoral student and Master of Law / PPGD / UFSC. Researcher at the Knowing Law Center - NECODI (UFSC / CNPq). Researcher at the Research Group on Modeling and Understanding of Social Systems: Law, State, Society and Politics (UFSC / CNPq). Researcher of the Research Project Lilith: Law and Intersectionalities. (CCJ / UFSC). CAPES scholarship. E-mail: amandai040@gmail.com
} 


\section{INTRODUCTION}

More than a source of entertainment and fun, music, as a product of human subjectivity, is able to convey messages and thoughts to virtually everyone who has contact with it. The mere fact of listening to a song, even if its content does not please us, can cause us to whistle it for days, so that we memorize it without even having such an intention. It is not by chance that we forget the date of the birthday of the grandparents, but we remember the telephone of the pharmacy sung in a jingle; by using hearing, music penetrates our unconscious without us being able to defend ourselves.

It is not by chance, either, that dictatorial regimes, such as the military dictatorship in Brazil of the 1970's, are so disturbed by songs - especially the popular ones. Music conveys messages and inspires ideals, being much more accessible than other cultural productions, such as literature: it takes just two or three minutes of listening to get in touch with a certain point of view.

The proposal of relating law and rock is not unprecedented. There is, for example, the work of Salo de Carvalho (2011), which deals with the criminology and counterculture of rock; the work of Russell Pearce, Brian Danitz and Romelia Leach (2005), who draw an analogy between lawyers and rockers; the research of Xavier Magnon (2011) that seeks to identify the vision of justice in the songs of Bob Dylan; the work of Germano Schwartz (2014) on Brazilian law and rock from the 1980s and, more recently, Amanda Oliveira's master dissertation (2016), which deals with the concepts of law present in Raul Seixas's work.

In the pursuit of this research, we will demonstrate how and why music, specifically rock, should be considered as an instrument for thinking the law. In a first moment, we will analyze the context of creation and production of rock, as well as its connection to the youth and movements of contestation. Next, we will make some considerations about the Brazilian military dictatorship, in order to demonstrate the importance of the contentious attitude of Raul Seixas, who through rock diffused his ideals of autonomy and freedom.

\section{LAW AND ROCK AND ROLL}

According to Paulo Chacon (1995, p. 18) "Rock is not [...] just a special type of music or rhythm. Restricting it to this is not recognizing his deep penetration into an (increasingly) significant share of Western societies." This is because although it is a musical genre, it has certain peculiarities. Chacon (1995, p.12) emphasizes dance, singing and auditory appeal as important characteristics, but what differentiates rock from

\footnotetext{
${ }^{4}$ Translated from the original in portuguese:: “O rock não é [...] apenas um tipo especial de música, de compasso ou de ritmo. Restringi-lo a isso é não reconhecer sua profunda penetração numa parcela (cada vez mais) significativa das sociedades ocidentais”.
} 
other musical styles would be its audience. In the words of the Author (1995, p. 18):

Rock is much more than a type of music: it has become a way of being, an optic of reality, a form of behavior. Rock is and is defined by its audience. That, because it is not uniform, to vary individually and collectively, requires the same polymorphism of rock, so that it adapts in time and space in function of the process of fusion (or shock) with the local culture and the changes that the years cause from generation to generation. More polymorphic still because its basic market, young, is dominated by the feeling of the search that makes difficult to reach the port of definition (and stagnation ...) . $^{5}$

The great interaction between rock and its audience, and the possible transgressive role attributed to rock can be corroborated from a brief analysis of the social conditions that allowed the emergence of this musical rhythm. According to Chacon (1995, p. 24), rock originated between the 50s and 60s, from three musical genres: pop music, defending conservative values of the time; the rhythm and blues, the black slope that almost exclusively shaped the rock; and country and western music, which conveyed the pain and suffering messages of white peasants.

The cultural industry also played a crucial role in the consolidation of rock. According to Alves (2002, p.31-32), the rhythm had its origins out of the market, but was soon absorbed by it.

As the agents of this cultural industry detected rock popularity, not only record companies but also radio, film and television were mobilized, and in a short time the songs at the same time synthesized the aspirations of American youth, and were sold as an exceptional commodity within the cultural market 6 .

However, according to Douglas Kellner (2001), it must be remembered that before a manipulator thing or sole source of entertainment, the media and the cultural industry convey their products in an attempt to attract as many people as possible. It is therefore not uncommon to find alienating and emancipatory discourses simultaneously in various cultural productions - including rock.

Simultaneously with the emergence of rock, Roszak (1972, p. 15-51) discusses the emergence of a socalled counterculture: an inverse culture, radically contrary to the ideals propagated by the then hegemonic culture, whose aim was to counteract "that society in which rulers justify themselves by invoking technical specialists, who in turn are justified by invoking scientific forms of knowledge. And beyond the authority of science

\footnotetext{
${ }^{5}$ Translated from the original in portuguese:: O rocké muito mais do que um tipo de música: ele se tornou uma maneira de ser, uma ótica da realidade, uma forma de comportamento. O rock é e se define pelo seu público. Que, por não ser uniforme, por variar individual e coletivamente, exige do rock a mesma polimorfia, para que se adapte no tempo e no espaço em função do processo de fusão (ou choque) com a cultura local e as mudanças que os anos provocam de geração a geração. Mais polimorfo ainda porque seu mercado básico, o jovem, é dominado pelo sentimento da busca que dificulta o alcance ao porto da definição (e da estagnação...).

${ }^{6}$ Translated from the original in portuguese: Na medida em que os agentes dessa indústria cultural detectaram a popularidade rock, não apenas as gravadoras, mas também o rádio, o cinema e a televisão foram mobilizados, e em pouco tempo as canções ao mesmo tempo em que sintetizavam aspirações da juventude americana constituíam-se como uma excepcional mercadoria no âmbito do mercado cultural.
} 
there can be no recourse $e^{71}$ that is, technocracy.

And one of the main vehicles of countercultural thinking, according to Roszak (1972, p. 51), was precisely rock. Although the Author (1972, p.270) has no appreciation for musical style, he agrees that rock bands are "prophets of the new generation. Probably the most vivid and timely expression of youthful rebellion (is) not only in the lyrics of the songs but also in all the guttural and rude style of sound and execution ${ }^{8 ”}$.

However, it is necessary to observe this relationship in a critical way, under penalty of imposing on rock a role that does not fit. According to Mugiatti (1973, p.19), there is a mythology erected in relation to rock, as the savation of the generation; this can be exemplified by the trajectory of Bob Dylan, who in early career composed songs apparently engaged, easily assimilated by the public because of the American disenchantment that prevailed at the time. However, from 1964 he began to turn away from politics, being appointed as a traitor to the counterculture. Bob Dylan, in a way, matures and begins to question the mythology of rock as a revolution in itself.

About the development of rock in Brazil, Alves (2002, p.35) states:

It was as a cultural commodity that [the rock] arrived in Brazil through the cinema, which fulfilled important role in its process of internationalization, not taking too long to trigger cultural practices. With great penetration in the country already at the time, Hollywood films were responsible for spreading the first rock songs in the country. Blackboard Jungle, is considered the first to make this release, because it counted in its soundtrack with the song Rock Around the Clock of the group Bill Haley and its Comets, one of the highlights of the then emergent American style. The youthful rebellion against the conservative society personified in the cinema in idols like James Dean had met his musical representative?.

According to Alves (2002, pp. 36-37), it is the success of the film Blackboard Jungle in national territory that allows the first recording of a rock and roll song in the country. The song Rock around the clock by Bill Haley and his comets, soundtrack of the film, was re-recorded by the samba singer, Nora Ney.

For Alves (2002, p.37) re-recording was a way of testing the rhythm that was bursting in the United States. The reception was positive, and soon the rockabilly style were incorporated into the young Brazilian culture. This fact is explained by the author (2002, pp. 38-44) as a consequence of the economic link between the United States and Latin America, especially with the beginning of the Cold War and the spread of the American

\footnotetext{
${ }^{7}$ Translated from the original in portuguese: "aquela sociedade na qual os governantes justificam-se invocando especialistas técnicos, que por sua vez justificam-se invocando formas cientificas de conhecimento. E além da autoridade da ciência não cabe recurso algum"

${ }^{8}$ Translated from original in portuguese: 'profetas' da nova geração. [...] Provavelmente a expressão mais vívida e oportuna da rebeldia dos jovens (está) não só nas letras das canções como em todo o estilo gutural e rouquenho do som e da execução"

${ }^{9}$ Translated from original in portuguese: "Foi enquanto mercadoria cultural que [o rock] aportou no Brasil por meio do cinema, que cumpriu importante papel em seu processo de internacionalização, não demorando muito para desencadear práticas culturais. Com grande penetração no país já na época, os filmes hollywoodianos foram os responsáveis pela divulgação dos primeiros 'rocks' no país. Sementes da Violência (Blackboard Jungle), filme de 1955, é considerado o primeiro a realizar esta divulgação, pois contava em sua trilha sonora com a canção Rock Around The Clock do grupo Bill Haley e seus Cometas, um dos destaques do então emergente estilo americano. A rebeldia juvenil contra a sociedade conservadora personificada no cinema em ídolos como James Dean encontrara seu representante musical."
} 
way of life. The process of industrialization in the country has also generated changes in relation to work and leisure time; consumption and leisure become complementary categories, so that the young public is also a consumer of the cultural industry.

For Chacon (1995, p.35) the arrival of rock and roll in the country occurred late and although some names have reached relative success, such as Cely Campello, Erasmo Carlos, Renato and their blue caps and even Roberto Carlos, "nobody will pass [...] of a reasonable level of composition. ${ }^{10 "}$ According to the Author (1995, p.35) in Brazil:" We will have neither hippies nor violence in the early brazilian rock; and in the year 1967, Sgt Pepper's year, Roberto and Erasmo did not exceed the short limits of the womanizer with a nice car $^{11}$."

This fact is explained by Napolitano (2007, pp. 87-94), because in the 60's the rhythm of great influence in Brazil was the Brazilian Popular Music - MPB, continuation of the Bossa Nova rhythm. Popularized mainly by television programs such as $O$ fino da da bossa, recorded by Tv Record, and song festivals, which revealed talents such as Raul Seixas himself, the rhythm prevailed for the valorization of the Brazilian people, with nationalism as a remarkable characteristic. In 1966, however, the early brazilian rock began to present itself as a rival, absorbing the rhythms of rock and roll of the 50's and producing the iê-iê-iê, which conquered the Brazilian youth.

The rivalry between the two musical genres was so great that representatives of MPB, such as Elis Regina, Gilberto Gil and Geraldo Vandré, among others, went to the streets in July 1967, in the dictatorship period, in the march that became known as a march against guitars, because the instrument would be a symbol of American imperialism. In the documentary Uma Noite em 67 (2010), directed by Renato Terra and Ricardo Calil, we have the testimony of Caetano Veloso, one of the MPB artists, who was against the brawl between MPB and iê-iê-iê (28:04-28:53):

I was against [the parade] and also was Nara [Leão]. We stayed at the Danúbio hotel, commenting on how strange, terrible and unlikely it was. Then the parade went down the street and Nara said, 'I'm depressed. This looks like a fascist parade of the Integralist Party'. And it was exactly what it seemed, understood? [...] For me it was a political decision to put an electric guitar in the music, to do ... for me and [Gilberto] Gil, to do the songs with rock band, with electric guitar was also a political attitude and diametrically opposed to the attitude of the march against electric guitar ${ }^{12}$.

In response, Napolitano (2007, p. 98) states that "the early brazilian rock has published in the press the priceless Iê-iê-iê’'s manifesto against the wave of envy'." The Author (2007, p. cites:

\footnotetext{
${ }^{10}$ Translated from original in portuguese: "ninguém vai passar [...] de um nível razoável de composição."

${ }^{11}$ Translated from the original in portuguese: "Não teremos nem hippies, nem violentos na Jovem Guarda; e em pleno ano de 1967, ano do Sgt. Pepper's, Roberto e Erasmo não ultrapassavam os curtos limites do boyzinho, do carrão, das mil mulheres”.

12 Translated from original in portuguese: Eu fui contra [a passeata] e a Nara [Leão], ficamos eu e a Nara no hotel Danúbio comentando como isso era uma coisa estranha, terrível e que não deveria estar acontecendo. Aí o negócio passou pela rua e a Nara disse 'Eu tô deprimida. Isso parece uma passeata fascista do Partido Integralista'. E era exatamente o que parecia, entendeu?. [...] Pra mim era uma decisão política botar uma guitarra elétrica na música, fazer... pra mim e pra [Gilberto] Gil, fazer as canções com
} 
We are aware that we have done much for those who need our help. We do not cry in our songs, we do not use protest to impress. If we decide to help, we do it with action. The proof of this is a multitude of things we have given to the benefit of various institutions. Making music claiming the poor man's life and living away from him is not our case. We prefer to sing to help them smile and, in the hour of need, to offer them substantial help. [...] it is an optimistic movement and there is no place for defeated. Notice that the hairy ones are happy boys. We never speak in our songs of sadness, of despair, of hunger, of war .... We do not want to win festivals or be called geniuses. We want the people to sing with us ${ }^{13}$.

Between the years of 67 and 68, however, both the young guard and the MPB began to show signs of exhaustion, with television programs being closed. According to Napolitano (2007, p.98), MPB continued its path, reinventing itself, while the young guard was diluted in romantic songs and in the tack of the 70's. As Chacon (1995, p. 43) rock wins some expression in the country:

Here, we began to accept rock as an option. Sure, we'd spent the first half of the decade singing MPB, figuring out how to overthrow the dictatorship, but the failure of the guerrillas led civil society to conquer rights in a less radical way. Through this gap came Os Mutantes, Raul Seixas and Secos e Molhados ${ }^{14}$.

In this way, it is important to understand what happened in the Brazilian political scenario of the 70's, a decade in which rock begins to gain some expression, including from the figure of Raul Seixas.

\section{THE BRAZILIAN 70S}

To better understand the clamor for a right to freedom in Raul Seixas' rock, we must understand what was happening in Brazil in the 70's, a period in which the artist lived the best years of his career. This is the purpose of this section: to present and problematize the Brazilian dictatorial period, time in which Raul Seixas composed his social, juridical and political songs.

Brazilian dictatorial period happened mostly during the 70s. Fausto (1995) says that at the mentioned time, the president João Goulart performed some social reforms that disliked the upper-middle class and the more conservative sectors of society (pp. 443-462). Thus, according to the author, right-wing political actors came to

banda de rock, com guitarra elétrica era uma atitude também política e diametralmente oposta à atitude da passeata contra as guitarras elétricas.

${ }^{13}$ Translated from original in portuguese: "Somos conscientes de que temos feito muito pelos necessitam da nossa ajuda. Não choramos nas nossas canções, não usamos do protesto para impressionar. Se nos decidimos a ajudar, fazemos com ação. A prova disso é um sem-número de — shows que temos dado em benefício de instituições várias. Fazer música reclamando a vida do pobre e viver distante dele não é nosso caso. Preferimos cantar para ajudá-los a sorrir e, na hora da necessidade, oferecer - lhes uma ajuda substancial. [...] trata - se de um movimento otimista e não há lugar para derrotados. Observe que os cabeludos são rapazes alegres. Não falamos jamais, nas nossas canções, de tristeza, de dos de cotovelo, de desespero, de fome, de seca, de guerra.[...] Não queremos ganhar festivais nem ser chamados de geniais. Queremos que o povo cante conosco."

${ }^{14}$ Translated from the original in portuguese: "Aqui, se recomeçava a aceitar o rock como uma opção. Certo, passáramos a primeira metade da década cantando Apesar de você enquanto bolávamos um meio de derrubar a ditadura, mas o fracasso da guerrilha levou a sociedade civil a conquistar direitos de uma maneira menos radical. Por essa brecha entraram Os Mutantes, Raul Seixas e os Secos e Molhados". 
believe that only a revolution would purify democracy, putting an end to the class struggle, to the power of trade unions and to the dangers of communism. (Fausto, 1995, p. 458).

In this way, José Murilo de Carvalho (2008) states that in 1964 General Castelo Branco was imposed as the new president of the Republic on a Congress already expurgated of many oppositionists (p. 158). With this, the Military Dictatorship began as a transitory government, in order to be passed on to civilians. This perspective was adopted by Castelo Branco and by his supporters - the castelistas. But even at the time, the perspective met strong opposition from the hardest political and military line. The hard military line had as its main objective to remove the foreign threat (socialism and communism) of the country.

The dictatorial period is divided by Carvalho (2008) into three phases: the first phase goes from 1964 to 1968 and corresponds to Castelo Branco's government and the first year of General Costa e Silva'a government. It was characterized by intense repressive activity followed by signs of slowing down. In the economy, it was a period of inflation, with a sharp fall in the minimum wage and small growth. It was the domain of the most liberal sectors of the armed forces, represented by General Castelo Branco. In the last year, 1968, the economy resumed the high growth rates of the 1950s (pp. 157-158).

We are interested, for the purposes of this article, in the general aspects of the Military Dictatorship's second phase (between 1968 and 1974), during which time Raul Seixas developed explicit songs about the right to freedom and other political issues.

According to Carvalho (2008), the second phase of the regime comprises the darkest periods of the country's history from the civil and political rights situation (pp. 157-158). It was a period marked by repression. In fact, the presidents of this period, Generals Costa e Silva and Médici, belonged to the hard military line (Carvalho, 2008, p. 160).

From the beginning of the dictatorship, the figure of Institutional Acts was present: they were a way of making the authoritarian practices legally valid. These acts, emanated by the chiefs of the executive, had the force of law and made great juridical e political modifications.

Let us not think that the dictatorship was not opposed. Carvalho (2008:161) states that in 1968 the military regime suffered much opposition, mainly by workers and students. However, when the Chamber of Deputies refused to allow one of its members to be prosecuted for delivering offensive speech to the Military, the government presented its authoritarian face by instituting what would be considered the most severe Institutional Act of any regime: AI-5. According to Carvalho (2008), Institutional Act No. 5 (AI-5) was the most radical of all, which has restricted political and civil rights. The Congress was closed and the president, General Costa e Silva, became dictatorial. Habeas corpus Act was suspended in case of crimes against national security and all acts arising from AI-5 were placed outside judicial review (p. 161). 
Simultaneously with these changes, Carvalho (2008) says political mandates were annulled and several deputies and councilors lost their political ${ }^{15}$ rights (p. 162). In 1969, however, President Costa e Silva passed away and his vice, Pedro Aleixo, was prevented from assuming. For Fausto (1995), the main reason why he did not become chief of the executive was that he was not military and, in addition, he had openly opposed AI-5 (p. 481).

Thus, a military group (junta) replaces Costa e Silva, provisionally, until General Medici assumed the presidency in October 1969, granting a new Constitution. According to Carvalho (2008), General Medici used many repressive measures. New national security law was introduced, including the death penalty by firing squad. In early 1970, prior censorship was introduced in newspapers, books and other media. This meant that radio or television publication or program had to be submitted to government censors before being brought to the public. Newspapers, radios and televisions were forced to live with the presence of the censor. Often the government issued instructions on matters that could not be mentioned (p. 162).

In addition to the period's repression, Fausto (1995) identifies political propaganda as one of the most effective weapons used by Medici for population control (p. 484). At this time, TV Globo became a reference in the telecommunications sector, acting, above all, as a government spokesperson.

As legal opposition was not allowed, until 1974, there was a common clash between leftist guerrillas and the military. Kidnappings, attacks, arbitrary arrests and torture happened. In this context, the right to individual freedom, so valued by Raul Seixas, was non-existent. According to Carvalho (2008), censorship of the press has eliminated freedom of opinion; There was no freedom of assembly; Parties were regulated and controlled by the government; The unions were under constant threat of intervention; Strikes were prohibited; The right to defense was curtailed by arbitrary arrests; Military justice judged civil crimes; The inviolability of home and correspondence did not exist; Physical integrity was violated by torture in the prisons of the government; The very right to life was disrespected. It was years of fear, in which the information and security organs acted without any control. (p. 163)

In spite of all this, Carvalho (2008) affirms that the Medici government enjoyed popularity (p. 168). This fact is explained by economic miracle reason, criticized indirectly by Raul Seixas in the song Ouro de Tolo (Fool's Gold). According to Fausto (1995), the period of the so-called 'miracle' extended from 1969 to 1973 , combining the extraordinary economic growth with relatively low rates of inflation. GDP grew at an annual

15 It is important to mention, on Civil and Political Rights, that despite the adoption of the International Covenant on Civil and Political Rights by the United Nations and member states, by resolution 2,200-A (XX), on December 16, 1966, Brazil only ratified it on January 24, 1992, long after the end of the military dictatorship. In Brazil, the Pact was approved by Legislative Decree 226 of December 12, 1991, and was promulgated by Decree No. 592/1992. The same was true of the International Covenant on Economic, Social and Cultural Rights, adopted by United Nations resolution 2,200-A (XXI) on December 16, 1966, and ratified only by Brazil on January 24, 1992 (approved by Legislative Decree 226, of December 12, 1991 and promulgated by Decree 591/1992). 
average of $11.2 \%$, peaking in 1973, with a $13 \%$ increase. The annual average inflation did not exceed $18 \%$. This really seemed like a miracle. Except that the phenomenon had an earthly explanation and could not last indefinitely (p. 485).

The author (1995) states that the weaknesses of the miracle were: (a) Excessive dependence on the financial system and international trade; and (b) Increasing need to rely on certain imported products, of which oil was the most important (pp. 486-488). These vulnerabilities were displayed in 1973, when the international community suffered from the Oil Crisis, whose consequences were felt by Brazil, according to Fausto (2009, p. 495).

Moreover, Fausto (1995) explains that the miracle had the negative aspects of contributing to social inequality, since the expansion of the industry favored mainly the middle and upper classes (pp. 486-487). There was also a great disproportion between the economic and social progress, and Brazil appeared with low indicators regarding the quality of life of its people.

Nevertheless, according to Carvalho (2008), the economic miracle coupled with the victory of the Brazilian soccer team in Mexico, evoked in the population a feeling of patriotic exaltation and xenophobic and reactionary nationalism (p. 168).

Médici failed to indicate a hard-line successor, so the military chose General Ernesto Geisel to take the presidency. He summarized the ideas of Castelo Branco and, according to Fausto (1995), he intended to create a slow, gradual and secure political opening (p. 489). The reasons are explained by the Author (1995): the power had been taken by the repressive organs, producing negative reflexes in the hierarchy of the Armed Forces. A lower-ranking officer could control information, decide on the life or death of people according to their insertion in the repressive apparatus, without his superior in the military hierarchy could contradict it. The basic functions and principles of the Armed Forces were thus distorted, bringing risks to the integrity of the military corporation. In order to restore the hierarchy, it was necessary to neutralize the hard line, to slow down the repression and orderly, to promote 'the return of the military to the barracks'. On the other hand, let us remember that 'relative democracy' was a goal sought by the castelista group since 1964. (p. 490)

In this way, Carvalho (2008) points to 1974 as the initial year of political openness, since it is the year in which restrictions on electoral propaganda are diminished (p. 173).

According to Carvalho (2008), in 1973, the Ordem dos Advogados do Brasil - OAB (Order of Brazilian Lawyers) assumed open opposition against the dictatorial government, although many lawyers and jurists continued to support it (pp. 185-186). Carvalho (2008) understands this opposition on the basis of professional interest, since the AI-5 excluded from the judicial assessment the acts performed in accordance with its provisions. Interventions in the Judiciary also demoralized justice as a whole. The judges were directly hit, but indirectly also 
the lawyers were harmed. (p. 186)

This interest, however, was not unique and Carvalho (2008) points to the belief in human rights, the theme of the 5th Annual Conference of the Order, as factors that have made it one of the trenches in defense of constitutional and civil legality (p. 186).

In relation to the culture in Brazil of the 1970s, Marcelo Ridenti (2009) states that the Geisel government, from 74, knew how to give place to the intellectuals and artists of the opposition (pp. 154-155). And states that, unlike the clashes between artists and the Medici government, the Geisel government encouraged a real growth in telecommunications, which resulted in the creation of a "cultural industry, not only television but also phonographic, editorial, Advertising agencies, etc (pp. 154-155). This fact, however, did not prevent censorship from acting repressively, limiting the circulation of works that were understood as inadequate.

For Riderti (2009), this incentive to cultural productions was a successful attempt to absorb opponents of the regime, diluting the artistic contestation they produced in the mercantile logic (p. 156).

Concerning music specifically, Jairo Severiano (2008) states that it is in the 70's that there is an expansion of musical regionalisms, at a level never before recorded (p. 420). Several artists from the Brazilian northeastern (such as Alceu Valença), Minas Gerais (like Beto Guedes) and Rio Grande do Sul (like Kleiton and Kledir), among many others, are singled out as the greatest hits of the time. In addition, soul music, samba, choro and tacky are singled out as prevailing musical styles.

It was not yet the decade of rock, as Severiano explains (2008): "[...] Brazilian rock lived in the 1970s a phase of low brightness, in which only the stars of Raul Seixas, Rita Lee, Erasmo Carlos and the trio Secos \& Molhados (p. 425).

It should be noted that the four most popular rock artists of the 70's have the contestation and rebellion ${ }^{16}$ as important characteristics: Erasmo Carlos causes controversy with the music Maria Joana, whose main theme is an apology for marijuana ${ }^{17}$; Secos \& Molhados used the different visual appeal in order to stand out, in addition to making strong criticisms of oppression in songs such as Sangue Latino (Latin Blood) ${ }^{18}$; and Rita Lee performs forceful criticism to the musical scene of the time, in the music Arrombaram a Festa (Break the party).

\footnotetext{
${ }^{16}$ Social criticism, at the time, was also hidden by means of ambiguous linguistic signs, as in the specific case of the song Debaixo dos Caracóis de Seus Cabelos (Under the Snails of his Hair), by Roberto Carlos, dedicated to the dictatorial exile of the musician Caetano Veloso.

${ }^{17}$ Excerpt from the brazilian song: "Eu quero Maria Joana / Eu quero Maria Joana / Eu sei (eu sei) / Que na vida tudo passa / O amor (o amor) / Vem como nuvem de fumaça (fumaça)". ("I want Maria Joana / I want Maria Joana / I know (I know) / That in life everything passes / Love (love) / Comes like a cloud of smoke (smoke)"). Maria Joana is an allusion to one of the popular names for marijuana.

${ }^{18}$ Excerpt from Brazilian the song: "Minha vida, meus mortos / Meus caminhos tortos / Meu Sangue Latino / Minh 'alma cativa" ("My life, my dead / My crooked ways / My Latin Blood / My 'captive soul). It is a denunciation to the poor conditions of the Latin American peoples, of "captive soul."
} 
Despite the absence of a strong movement in Brazilian rock, Raul and the other artists have introduced the rhythm, which will be popularized in the 80 's. We now turn to the peculiarities of Raul Seixas and his clamor for Right to freedom.

\section{THE RIGHT TO FREEDOM IN RAUL SEIXA'S ALTERNATIVE SOCIETY}

Raul Seixas was born in Salvador, on June 28, 1945, the son of a middle-class family. His fascination for literature and philosophy, also his interest in metaphysical and philosophical matters, grounded his entire musical career. If during a certain period of Raul's life he perceived music as secondary, when he finally came into contact with rock and roll, through his American neighbors, he discovered that he could leave a message to the world from this vehicle. In an interview, he states that he saw that literature is a very difficult thing to do here, to communicate as fast as music. (Seixas, 1990, p. 87).

For him, Rock was much more than a dance. It was made of the whole being (Bahiana, 1990, p. 14), and quickly clarifies the reason for such admiration: What got him was everything, not just music. It was all rock behavior. Because before the kids were not kids, they followed the adult pattern, that imitation of the little man, with no identity. But when Bill Halley arrived with Rock Around the Clock (the song of the movie) it was crazy for him. He and some friends broke the whole movie, it was a freer thing, it was his exit door, it was his turn to speak, to climb on a stool and say that he was there. He felt it was going to be an incredible revolution. At the time, he thought that the young people were going to conquer the world. (Bahiana, 1990, p. 14).

The desire to be a writer was never abandoned by Raul, but his school performance was not one of the best. He said, he was a failure at school. The school did not tell him anything he wanted to know. All he learned was in books, at home, or on the street. He repeated five times the 2nd grade. (Bahiana, 1990, p. 15).

Despite this, Raul had a great need to talk about various subjects. This need was softened by the creation of the band Relâmpagos do Rock (Lightning of the Rock), later baptized of The Panthers and, finally, Os Panteras (The Panthers, in portuguese). According to Raul, the group lasted eight years. In the beginning, they paid to appear on TV, and introduced their songs as 'cowboy music'. (Bahiana, 1990, p. 19).

In addition to performing on local TV, the band gained prestige in the Bahia's scenery, being considered the most expensive set in the city of Salvador and even dividing the stage with stars from Jovem Guarda (the first rock and roll artists in Brazil), such as Roberto Carlos and Wanderléa.

It is interesting to point out that, by making music a form of communication, to transmit his messages, Raul comes to lecture about Freud's theory in the middle of his shows with Os Panteras. To him, it was incredible to speak of ego and superego to the people from nowhere land, who understood nothing, absolutely nothing. But 
he did it. He said that if he was not behind the stage, he would be behind a teacher's chair. If he wouldnot me at the stage, he would certainly be a teacher. (Bahiana, 1990, p. 20).

Although educated and interested in subjects such as philosophy and psychology, he did not integrate the academic environment - which did not prevent him from developing his ideas. Through his songs Raul managed to problematize and carry out strong criticism of society. If academics publish books and scientific articles, Raul Seixas had his lyrics, melodies and performances, sometimes even more striking and certainly with great reach in the population, certainly more than the scientific books. Mauro (1990) recalls the words of the artist, after already successful musically. He used to say that he, who studied history, philosophy, literature, Latin, had something to say. He did not bring an imposed thing, a label - he was not padding out. He emphasized that he had a solid base for his actions, because he read a lot of treatises. His intention was to show that he did research to say what we wanted to say.

Raul needed to legitimize his work as the result of research and not mere chance. For him, it was not just about communicate his feelings, but about communicate a critical and clear message of the society of his time. This need to legitimize his message reminds us of the discussion between art and mass culture: it is as if only one type of cultural artifact deserves importance. However, in an interview, it is Raul himself who will review this simplistic attitude in an interview for a radio station in the city of Joaçaba, Santa Catarina State, in 1976 ${ }^{19}$, at 03:51 ', saying that art is the social mirror of an era, because what a singer does reflects the social moment in which he is living.

It is important to emphasize that, before launching himself as a singer, Raul Seixas met the one who would become one of his several composing partners, Paulo Coelho. His brother Plínio, in the documentary O Início, o fim e o meio (The Beginning, the End and the Middle) (25:14'), reports that the two did not meet: in fact, Raul is the one who went after Paulo. The reason for this search was an article about flying saucers, written by Paulo in the magazine A Pomba (The Dove), that very intrigued Raul. From this initial contact, the two began to relate and to wage a turbulent friendship.

The most famous composing partner of Raul, Paulo Coelho comments on the process of composition of the two, in Video document Volume $02^{20}(07: 00$ '), saying that Raul was very important to him, because Raul taught him how to write.

If, on the one hand, Raul taught Paul how to transmit his messages in an easy and accessible way to the general public, on the other hand, Paul presented to Raul something that, along with his philosophical and political

\footnotetext{
${ }^{19}$ Retrieved January 9, 2016, from http://migre.me/sHS7d.

20 It's a collection of thirteen vídeos edited by Raul Seixas's oficial fan club, retrieved January 15, 2016, from http://migre.me/sHT4w.
} 
readings, will be an element present throughout his life work: the occultism, especially Thelema, esoteric philosophy created by Aleister Crowley, famous English magician. According to Luiz Lima (2007, p. 32), the singer claimed to be anarchist and like Proudhon, at the same time he adored Aleister Crowley.

Through Paulo, Raul got in touch with Marcelo Motta, main promoter of Crowley's ideas in Brazil, becoming part of the Astrum Argentum (Silver Star in latin, better known as A. .A), a society created by Crowley, and part of the Ordo Templi Orientis (Order of the Temple of the East, in Latin, better known as O.T.O), a society reformulated by the same magician, also based on thelemic principles. According to Lima (2007) Raul reached the rank of neophyte in both societies (p.36).

It was from the teachings of Crowley that Raul conceived the idea of Law based on individual freedom. According to O.T.O, more than a religious postulate, the Law of Thelema can be seen as a philosophy, a social proposal, or the sum of it all. According to A. . $\mathrm{A}^{21}$, Thelema means will, in Greek, which explains the axioms that summarize it: do what thou wilt shall be the whole of the Law and love is the law, love under will.

According to the O.T.O., this will preached by Thelema's Law is far from being linked to simple human desires and whims: On the contrary, it refers to the strict mission of discovering and realizing the true nature, which is equivalent to the divinity within each individual.

The valuation of each individual is also evident in the axioms, every man and every woman is a star and there is no God but man, in the sense of enhancing appreciation and respect for each individual as a single deity, whose duty it is to accomplish his true will. It is interesting to note that the Thelemic system has its own declaration of human rights, written on a page in the year 1941 by Crowley, in order to make his philosophy more accessible. This statement began to be read by Raul in his concerts when he sang the song Sociedade Alternativa, a song inspired by thelemic principles.

It is necessary to take into account, however, Lima's warning (2007): Raul was an agnostic who was only curious about the occult teachings; he re-signifies Crowley's doctrines, giving them social and political dimension, as realized, for example, in the music Sociedade Alternativa (p. 49).

Present on the singer's best-selling album, Gita, released in 1974, the song Sociedade Alternativa marks a transition. According to Rada Neto (2012), since 1973, Paulo Coelho and Raul Seixas claimed to be involved in creating a movement capable of providing new behavioral values and helping in the liberation of people. Its proposal included radically transforming the organization of society, including its traditional way of thinking and explaining the world. And their main weapon of combat was the systematic use of the irony. (p. 248)

Thus, before the release of Gita, Raul and Paulo synthesized these ideas into a comic manifesto called

\footnotetext{
${ }^{21}$ Retrieved January 15, 2016, from http://migre.me/sHSLb.
} 
The Krig-Ha Foundation, material that was distributed during the concerts. According to Rada Neto (2012), the comic is permeated with esoteric and religious symbologies, calling on people, not to institute a new government, but to combat all forms of oppression (pp. 248-254).

At the same time, Rada Neto (2012) tells us that Paulo Coelho writes in May 1974 an article for the Revista Planeta (Planet Magazine, in English), entitled As Sociedades Alternativas (The Alternative Societies), in which he said that he, Raul and their women created in September 1973, the Alternative Society in Brazil with 3,000 members. (Rada Neto, 2012, pp. 256-257).

In addition, Raul tries to legitimize this so-called alternative society by linking it to names like John Lennon, whose involvement with Raul has never been proven. Some time later, Raul changes his perspective on the Alternative Society: he warned that the Alternative Society was not a club or a political party, but an idea. (Seixas, 1996, p. 22).

However, in 1974, these ideas displeased the military government, which not only collects all the comic books, but also arrests and interrogates Paulo Coelho and Raul Seixas ${ }^{22}$. Scared, they choose a self-exile ${ }^{23}$ and decide to leave for the United States. From there, they will return a few months later, in July 1974, thanks to the successful sales of Gita, which had been completed before the exile. According to Raul, the staff of the Brazilian Consulate came to his home to say that Gita was making the greatest success and that he neede to go back to Brazil as a national patrimony. (Seixas, 1996, p. 22).

It is in Gita, in which most of the songs are also signed by Paulo Coelho, which is recorded the song Sociedade Alternativa, fruit of their partnership. For Frans (2000), the disc brought the inquiries of two artists involved with esoteric studies and concerned with the construction of the utopia of both - the Alternative Society (p. 104).

The song Sociedade Alternativa, whose main theme is a synthesis of thelemic precepts, welcomes the coming of a new era and affirms the right to freedom as a primordial law. Marked by the accentuated drumming, this fast-paced rock brings direct quotes to passages from Liber AL vel Legis, The Book of the Law, a crucial work of Thelemic doctrine, as well as references to Crowley.

The first of these references are the verses " Do what thou wilt shall be the whole of the Law," which

\footnotetext{
${ }^{22}$ About that, it is necessary to make some considerations. Rada Neto (2012, p.260) states that despite having found documents proving that Raul had been called to testify, he did not find the transcription of these testimonies. It also states that there is no evidence that Raul had been arrested, although he had his residence searched and suffered assaults. As for Paulo and Adalgisa, the Author (2012, p.263) was able to locate the transcript of each person's testimonies, as well as the Control Sheets, according to which the two were militants of leftist parties.

${ }^{23}$ This subject is also surrounded by controversies, since, in several interviews, Raul states that he was invited to leave the country, that is, exiled. However, Rada Neto (2012, p.259) transcribes Roberto Menescal's speech, stating that there was no imposed exile, but rather problems before which Raul and Paulo chose to leave the country.
} 
appears in Chapter 1, verse 40. By singing them, the music stops suddenly, so that the voice is highlighted, giving greater prominence to this message that is the core of thelemic thinking: to discover and realize their true will. However, more than this, we understand that Raul, in this song, also invites individuals to realize their desires, however uncommon, without fear of repression. This fact is provided by the verses, translated to english: "If I want and you want / To take a bath of hat / Or to wait Santa Claus / Or to discuss Carlos Gardel / Then go! / Do what you want / For is all / Of the Law!"24.

In another moment of the song, the following verses appear: "Every man and every woman is a star," which are also present in the Book of the Law (Chapter 1, verse 3). These verses are not sung, but spoken: or rather, shouted over the melody. This is a reference to the valorization of the human, in the thelemic system, each individual is a deity, a universe, a star of its own. Everyone should be valued as such. In singing these verses, Raul reiterates this thelemic view of individual freedom.

There is in the song a mention to Crowley and his postulates in the verses: "- The number 666 / is called Aleister Crowley" and "- Thelema's Law", the verses are shouted. Crowley adopted the number 666 and the nomenclature A Great Beast, as a way of opposing the conservative values of his time. The Law of Thelema is none other than the Law of Will: "Do what thou wilt."

The last direct quotation is present in the verses, also shouted: "- The Law of the strong / That is our law / And the joy of the world" is a cut from chapter 2, verse 21 of the Book of the Law: "this is the law of the strong: this is our law and the joy of the world". This is a clear warning to the fact that the Law of Thelema is made only for the few, for the strong, and we also understand that the Law of the Raul's Alternative Society is intended for nonconformists and open-minded people.

Thus, with the clear thelemic influence, Paulo Coelho and Raul Seixas represent, in Alternative Society, an extraterrestrial right: a metaphysical right, according to which the only law would be freedom. We can observe the transposition that Raul and his composing partner make of Thelema's Law for music. Based on the duality of repressive society $\mathrm{x}$ alternative society, the idea of having an alternative to oppression and imposition on human individuality, once confined to an hermetic occult circle and available only to the initiates, is renamed, mixed with other elements and thus made accessible to the public through the media.

As far as musical parameters and listening are concerned, it is a song which at any moment evokes the feeling of protest; the strategic stops in the melody and the shouted verses accentuate the main message of the song, that is, the propagation of a right to freedom. Raul's performance also fits perfectly in this scenario: in his shows, at the end of the song, he retired from the stage and returned with a paper, in which was written the Liber

\footnotetext{
${ }^{24}$ Translated from the original in portuguese: "Se eu quero e você quer / Toar banho de chapéu / Ou esperar Papai Noel / Ou discutir Carlos Gardel / Então vá! / Faça o que tu queres / Pois é tudo da lei!”
} 
$\mathrm{O} z$, the declaration of thelemic rights.

Liber Oz's reading (Liber de $\mathrm{Oz}$ ) emphatically and invitingly strengthens the idea of nonconformity and the need to fight for freedom not only political but also morally and socially. It seems possible to perceive, therefore, the use of Raul's space in the media to challenge and claim for a right to freedom, withdrawn by the dictatorship.

Concerning the reception, the music was considered a true anthem of contestation, although it was not created with this specific intention. Buda (2000), for example, states that during a strike in the São Paulo ABC, the strikers justly sang the song Sociedade Alternativa. In addition, the author also reveals the desire of presidential candidate Luís Inácio Lula da Silva years later to re-record the song as a campaign jingle in the voice of a Raul cover (p. 33). The cover would have contacted Toninho Buda, who explained to him the anarchic ideals of Raul present in the song, reason why it was not re-recorded like jingle.

With the ideals of the Alternative Society, Raul Seixas occupied a polarized space by singing openly against the established dictatorial regime. Inspired by Thelema's Law and transposing it to the political situation in Brazil, the singer was able to mobilize and make his fans and admirers aware of the importance of a full right to freedom. In fact, the fact of having won four gold records in his career greatly suggests Raul's acceptance by the public. Teixeira (2008) analyzes in depth the question of the reception of the singer's work, identifying the existence of several fans and networks of sociability created to discuss information about the artist (pp. 112-173).

All this seems to lead one to believe that, in terms of reception, Raul was not only well accepted by popular audiences, but also remained present in the Brazilian musical scene even after his death: the annual parade held in São Paulo by fans on the date of his death ${ }^{25}$; the annual concerts ${ }^{26}$ in which several artists interpret their songs; the various covers ${ }^{27}$, all are elements that point to a permanence and appreciation of the figure of the singer, demonstrating that the message of a right to freedom and the search for an Alternative Society still remain.

\section{CONCLUSIONS}

Beyond the aesthetic dimension, Art is a form of communication. As Raul stated, "art is the social mirror of an era, of a moment". (PASSOS, 1990, p. 107). Starting from this same premise, several areas of knowledge have already set out to identify and analyze the connection between the cultural productions, erudite or popular, and the society in which they arose. In this way, they came to the conclusion that these productions are not neutral,

\footnotetext{
${ }^{25}$ More information at http://migreme/sHW6d. Accessed on January 15, 2016.

${ }^{26}$ This is the Project called O Baú do Raul (Raul's Chest). More information at http://migre.me/sHW7U. Accessed on January $15,2016$.
} 
and at the same time they influence, they are influenced by the opinions and thoughts of the people.

This fact is no different concerning music. Initially conceived as a young people's rhythm, music, especially rock, soon became a youth movement: artists such as The Beatles and Bob Dylan influenced an entire generation with their words and lyrics of contestation and need for change. Although the rock is not seen as a revolution in itself, it has brought different opinions on common matters, like puritan conservatism. In this sense, rock became an interesting source of analysis to understand the ruptures of society.

In Law studies, the connection between rights, Law and Music is an approach little explored. Researches in Law and Literature can already be found easily, but the picture changes with regard to music. In view of this panorama, this article sought to establish a connection, even if incipient, between law and rock, as well as to demonstrate how the songs can be used as a way of claiming rights, relating the music and the artist to their context, as the example of Raul Seixas and his Alternative Society.

After clarifying the reasons why music can be considered a valuable source of studies and contextualize the period in which our example was set, we sought to conduct a broad analysis, using interviews, presentations and the music Alternative Society.

Influenced by Crowley's mysticism and countercultural anarchism, and opposing to all forms of oppression, Raul Seixas calls for the effectiveness of a metaphysical right, the freedom right. Based on Crowley's Thelema Law, and giving it a new interpretation and meaning, Raul calls for the right to do whatever he wants, whenever and however he pleases. Thus, using this idea of a right to freedom, Raul contrasts the Alternative Society with the dictatorial and conservative society of Brazil of the 70 s.

\section{FAÇA O QUE TU QUERES POIS É TUDO DA LEI: CONTRIBUIÇÕES DE RAUL SEIXAS PARA O ESTUDO DO DIREITO}

\section{Resumo}

O presente artigo busca demonstrar de que forma o rock, produto midiático fruto da cultura de massa, pode ser utilizado como veículo de contestação e luta social, a partir do exemplo de Raul Seixas. Tendo alcançado sucesso de público no período ditatorial brasileiro, o artista procurou utilizar seu status social e sua audiência para disseminar ideais relativos à liberdade individual. Conhecedor da Lei de Thelema, Raul ressignificou esse postulado esotérico e o aplicou no campo social e político, de modo a difundir suas premissas como forma de luta e resistência contra a ditadura. $\mathrm{O}$ artigo, nesse sentido, irá propor a utilização do rock como forma de se refletir

\footnotetext{
${ }^{27}$ More information at http://migre.me/sHW7U.Accessed on January 15, 2016.
} 
sobre o direito. Para tanto, metodologicamente, se buscará investigar como e por que o rock deve ser considerado uma promissora fonte de estudos jurídicos; na sequência, será contextualizada a situação brasileira da década de 70, época de maior sucesso de Raul Seixas, e investigada a maneira como o artista utilizou de seu lugar de destaque para denunciar e contestar o status quo.

Palavras-Chave: Liberdade; Direito \& Música; Raul Seixas; Rock; Conhecimento jurídico.

\section{REFERENCES}

ABAD, Manuel D. Las conciencias del rock. Um largo trayeto del inconformismo a la integración. In., Ábaco, 2 Epoca, n. 9/10, Tolerância frente a exclusión (1996). Published por Centro de Iniciativas culturales y estudios econonomicos y sociales (CICESS).p. 111-118.

ALVES, Luciano. Flores no deserto: a Legião Urbana em seu próprio tempo. 2002. 151 f. Dissertação (Mestrado em História), Universidade Federal de Uberlândia, Uberlândia, 2002. Disponível em: <http://migre.me/sINlj>. Acesso em 06 dez. 2015.

BAHIANA, Ana. Eu em noites de sol. In: PASSOS, Sílvio (org.). Raul Seixas por ele mesmo. São Paulo: Martin Claret, 1990.p. 11-39.

BOSCATO, Luiz Alberto de Lima. Vivendo a Sociedade Alternativa: Raul Seixas no Panorama da Contracultura Jovem. 2006. 258 f. Tese (Doutorado em História) - Faculdade de Filosofia, Letras e Ciências Humanas, Universidade de São Paulo, São Paulo. 2006. Disponível em: <http://migre.me/sINvu>. Acesso em 17 jan. 2016.

BUDA, Toninho. Os movimentos alternativos. In: PASSOS, Sylvio (org). Raul Seixas: uma antologia. São Paulo, SP: Martin Claret, 2000. p. 22.

CARVALHO, José Murilo de. Cidadania no Brasil: o longo caminho. Rio de Janeiro: Civilização brasileira, 2008.

CARVALHO, Salo de. Das Subculturas Desviantes ao Tribalismo Urbano (Itinerários da Criminologia Cultural vol.12, no. 01, Rio de Janeiro, 2019. pp. 100-121 
através do Movimento Punk). In: LINCK, José Antônio Gerzson; MAYORA, Marcelo; PINTO NETO, Moysés; CARVALHO, Salo de. Criminologia cultural e rock. Rio de Janeiro: Lumen Juris, 2011, p. 149-223. Disponível em: <http://migre.me/skHtF>. Acesso em 07 dez. 2015.

CARVALHO, Walter. Raul: o início, o fim e o meio.2012, 100 min.

CHACON, Paulo. O que é rock?. São Paulo: Brasiliense, 1995. Disponível em: < https://pt.scribd.com/doc/53906055/O-Que-e-Rock-Paulo-Chacon>. Acesso em 06 dez. 2015.

COLI, Jorge. O que éarte?. São Paulo: Brasiliense, 1995.

COSTA, Marisa Vorraber; SILVEIRA, Rosa Hessel; SOMMER, Luis Henrique. Estudos culturais, educação e pedagogia. Rev. Bras. Educ, Rio de Janeiro , n. 23,p. 36-61,Aug. 2003 . Disponível em: $<$ http://migre.me/rZpQm>. Acesso em 01 nov. 2015.

CROWLEY, Aleister. Liber AL vel Legis: O Livro da Lei. Disponível em: < http://migre.me/sINAN>. Acesso em 17 jan. 2016.

ESCOSTEGUY, Ana Carolina. Os Estudos Culturais. In: HOHLFELD,Antonio;MARTINO, Luiz C.; FRANÇ A, Vera Veiga (org.). Teorias da Comunicação:conceitos, escolas e tendências. Petrópolis, RJ: Vozes, 2001, p.151170. Disponível em: < http://migreme/sINFa >. Acesso em 06 dez. 2015.

ESSINGER, Silvio. O Baú do Raul Revirado. Rio de Janeiro: Ediouro, 2005.

FAUSTO, Boris. História do Brasil. São Paulo: Edusp, 1995.

FERREIRA, Bianca Márcia. A Sociologia de Raul Seixas - A arte como espelho social de sua época. 96 f. 2013. Dissertação (Mestrado em Sociologia), Faculdade de Filosofia e Ciências Humanas, Universidade Federal de Minas Gerais, Belo Horizonte. 2013. Disponível em: <http://migreme/sINFX>. Acesso em 17 jan. 2016.

FRANS, Elton. Raul Seixas: a história que não foi contada. São Paulo: Irmãos Vitale, 2000. 
GRUBBA, L. S; OLIVEIRA, A. M. Por um direito à liberdade: Raul Seixas e a Sociedade Alternativa. In: Culturas Jurídicas, v. 4, n. 7,2017.p. 61-86.

KELLNER, Douglas. A cultura da Mídia: estudos culturais, identidade e política entre o moderno e o pósmoderno. Bauru, SP: EDUSC, 2001.

LIMA, Luiz. Vivendo a Sociedade Alternativa: Raul Seixas no seu Tempo. São Paulo: Terceira Margem, 2007.

MAGNON, Xavier. La vision de la justice dans les chansons de Bob Dylan (1962-2001). In: MASTOR, Wanda; MARGUÉNAUD, Jean-Pierre; MARCHADIER, Fabien (org). Droit et rock. Paris: Dalloz, p.65-78, 2011.

MAURO, André. O último anarquista. In: PASSOS, Sílvio (org.). Raul Seixas por ele mesmo. São Paulo: Martin Claret, 1990. p. 41-61.

MUGIATTI, Roberto. Rock, o grito e o mito: a música pop como forma de comunicação e contracultura. Petrópolis: Vozes, 1973.

NAPOLITANO, Marcos. A síncope das ideias: a questão da tradição na música popular brasileira. São Paulo: Editora Fundação Perseu Abramo, 2007.

OLIVEIRA, Amanda Muniz. Faça o que tu queres, pois é tudo da lei: representações do direito no rock de Raul Seixas a partir dos estudos de Douglas Kellner. 252 f. Dissertação (Mestrado em Direito) Centro de Ciências Jurídicas, Universidade Federal de Santa Catarina, Florianópolis. 2016.

OLIVEIRA, Amanda Muniz; RODRIGUES, Horácio Wanderlei. "Let me sing my rock and roll": notas sobre direito, rock e sociedade. Redes - Revista Eletrônica Direito e Sociedade, Canoas, UnilaSalle, v. 6, n. 1, maio 2018. p. 11-31. Disponível em: <https://revistas.unilasalle.edu.br/index.php/redes/article/view/3408/pdf>. Acesso em: 5 jun. 2018.

ORTIZ, Renato. Estudos culturais. Tempo Social, São Paulo, v. 16, n. 1, p. 119-127, June 2004. Disponível em: <http://migre.me/rZpU0>. Acesso em 01 nov. 2015. 
PEARCE, R.G., DANITZ, B. \& LEACH, R.S. Revitalizing the Lawyer-Poet: what lawyers can learn from rock and roll. Widener Law Journal, volume 14, 2005, p. 907-922. Disponível: <http://migre.me/skHxi> Acesso em 07 dez. 2015.

RADA NETO, José. As aventuras de Raul Seixas no campo musical: trajetória artística e relaçóes com a indústria fonográfica(1967-1974). 2012. 347 f. Dissertação (Mestrado em Sociologia Política) - Centro de Filosofia e Ciências Humanas, Universidade Federal de Santa Catarina, Florianópolis, 2012. Disponível em: < http://migreme/sINSa >. Acesso em 06 dez. 2015.

RAUL SEIXAS. Só pra variar. In: Abre-te Sésamo: Sony Music Enterteinment,1980. Faixa 05. CD.

RAUL SEIXAS. Sociedade Alternativa. Sociedade Alternativa. In: Gita: Philips, 1974. Faixa 07. CD.

RIDENTI, Marcelo. Cultura e política: os anos 1960-1970 e sua herança. In: FERREIRA, Jorge; DELGADO, Lucilia de Almeida Neves. O Brasil Republicano - o tempo da ditadura: regime militar e movimentos sociais em fins do século XX. Rio de Janeiro: Civilização Brasileira, 2009. p. 135-166.

ROSZAK, Theodore. A contracultura. Petrópolis: Vozes, 1972.

SCHWARTZ, Germano. Direito \& Rock: o BRock e as expectativas normativas da Constituição de 1988 e do Junho de 2013. Porto Alegre: Livraria do Advogado, 2014. E-book não paginado.

SEIXAS, Kika (org). Raul Rock Seixas. São Paulo: Globo, 1996.

SEIXAS, Raul. Krig-Ha, Bandolo! (O Grito de Guerra). In: PASSOS, Sylvio (org.). Raul Seixas por ele mesmo. São Paulo: Martin Claret, 1990.p. 7-10.

SEVERIANO, Jairo. Uma história da música popular brasileira: das origens à modernidade. São Paulo: Ed. 34, 2008.

SOUZA, Tárik de. (org). Baú do Raul. São Paulo: Globo, 1992. 
TEIXEIRA, Rosana Câmara. KRIG-HA, BANDOLO! Cuidado, aí vem Raul Seixas!. Rio de Janeiro: Editora 7 Letras, 2008.

TERRA, Renato; CALIL, Ricardo, ACCIOLY, Beth. Uma noite em 67. [Filme-vídeo]. Produção de Beth Accioly, direção de Renato Terra e Ricardo Calil. Record Entretenimento. 2010, 93 min. Color. Son. Disponível em: < https://www.youtube.com/watch?v=FOsXaaW4Pkk>. Acesso em 06 dez. 2015.

THOMPSON, John. A mídia e a modernidade: uma teoria social da mídia. Petrópolis: Vozes, 1998.

UEHLEIN, Joel. Na overture into the future: the music of social justice. In., Labor Forum. n. 9. United States: Sage Publications, 2001.p.24-34.

Trabalho enviado em 31 de agosto de 2018

Aceito em 12 de janeiro de 2019 